\title{
Influence of the Team Value of Professional Football Clubs on Their Success in Sports
}

\author{
Roman Warias ${ }^{1}$, Sebastian Block ${ }^{2, *}$ \\ ${ }^{1}$ Technical University of Kosice, Faculty of Economics, Slovak Republic \\ ${ }^{2}$ School of Economics and Law, Department of Business and Economics, Badensche Straße 52, 10825 \\ Berlin, Germany
}

\begin{abstract}
Research background: Professional football is becoming more and more commercialized. The most recent attempt to establish a "Super League" failed, but the big football clubs are nevertheless trying to generate success in sports through increasingly high player transfers.

Purpose of the article: The aim of this paper is to empirically test the above statements and assumptions. On the one hand, the question arises whether the placement in a ranking table of a competition depends on the investment volume. At the same time, it is analyzed whether this relationship exhibits stability over time. Table placement was chosen because it has a direct influence on the distribution of funds in a competition. In addition, individual matches are analyzed to determine whether the investment volume has a statistically significant influence on winning a match.

Methods: The years 2014 to 2020 of the competitions of one of the top five European leagues, the German Bundesliga, are prepared in a database. In addition to the player results and table positions, the market values of the players in the season are used. All data is taken from the website Transfermarkt.de. In the context of the table rankings, a regression analysis is performed to explain the place in the table by the market value of the team. When analyzing individual matches, the team value on the field in each case is determined and the differences between the values of the teams playing are established. These differences are explained as a dependent variable in a regression line with three dummy variables: won, lost, and draw.

Findings \& Value added: The results enable the management of football clubs to make an investment decision for a successful future. They show, on the one hand, whether the team value has an influence on the league position and, on the other hand, on the match result.
\end{abstract}

Keywords: football; team value; top leagues; transfer market; success in sports

JEL Classification: $A 10 ; B 16 ; C 12 ; C 21 ; L 83 ; Z 21$

\footnotetext{
*Corresponding author: sebastian.block@hwr-berlin.de
} 


\section{Introduction}

Football is the most popular sport and inspires millions of people worldwide. While amateur football is mainly about enjoying the game and feeling part of the team, professional football is more about success and economic factors. Over decades research regarding professional football has been conducted. For example, Muller et al. (2017) found that a data driven approach to estimating market value of players overcomes crowdsourcings practical limitations. Elaad (2019) researched if regulation restrictions on the promotion of reserve teams affect performance. Truong et al. (2021) and Dimic et al. (2018) researched stock returns in different ways. Gender differences in football have been part of research as well (Bradley et al., 2014) as well as research regarding transfer systems (Hoey et al., 2021). Other sporting abilities have been researched in precise detail by Morin et al. (2021). Hackinger (2019) investigated if football coaches let players with high transfer fees play longer despite bad performance and came to the conclusion that professional sports teams in Germany act rationally. The issue of property rights, in particular, is of immense economic importance for professional clubs, as they can be used to achieve sporting as well as economic success. In order to achieve their respective sporting and financial goals, clubs are increasingly willing to sign new players under property rights or to sell players who are already under contract. In this context, ever higher transfer fees are paid from season to season. Transfer spending worldwide has long since broken through the billion-euro barrier. In 2020, a total of USD 5.63 billion was invested in international transfers of players in professional football, and the peak value of USD 7.35 billion the year before (FIFA, 2021, p. 9). The clubs in the big five European leagues, 1st Football Bundesliga, Serie-A, Ligue 1, Premiere Division, and the Premier League, stand out in particular with their high transfer spending. Of the aforementioned USD 5.63 billion, they invested a total of approximately USD 4.1 billion in new players (The Guardian, 2020), which corresponds to approximately $73 \%$ of the total global transfer volume. The problem that arises is whether the high transfer payments for new players are always accompanied by sporting success. In order to investigate this issue, the five major European professional football leagues will be evaluated on the basis of a data set.

\section{Theoretical Framework}

\subsection{Property Rights}

First, the term "property rights" must be explained. The economic concept of property rights theory refers to the allocation of competencies in the use of resources (Schäfer \& Ott, 2020, p. 659). The allocation and specification of these individual rights form the so-called Bundle of Property Rights. This bundle specifies own and third party rights for each property (Schmid, 2013, p. 47). It is important to note that own rights are always limited where third party rights are infringed (Schmid, 2013, p. 48). Thus, while it is legally possible to burn property in a piece of wood, use it as a walking stick, sell it, or give it away, it is not legally possible to beat someone up with it (Söllner, 2015, p. 130). However, in the property rights approach, when goods are exchanged, the focus is not on their physical property. Rather, what matters is the transfer of property rights, which are decisive for the value of a good and its exchange relation as well as its intensity of use (Demsetz, 1967, p. 347; Schmid, 2013, p. 48).

Basically, it can be stated that there are three types of property rights which are classified according to their scope or legal protection (Schmid, 2013, p. 48).

These are distinguished in the following: 
- Absolute property rights must be observed by everyone and are characterized by the fact that the right holder can exclude anyone from using the right (exclusion function $=$ negative scope of application) and can therefore use the right alone (use function $=$ positive scope of application). Absolute property rights can be divided into in rem property rights, intangible property rights, and personal rights.

- Relative property rights, in contrast to absolute property rights, apply only inter parts. This means that they only have a legal effect between persons who are in a creditor-debtor relationship, for example the parties of a contract arising from employment, purchase, rental, and lease agreements.

- Other property rights are non-legal property rights, family rights, or relationships (e.g., rights arising from social friendship, love, and neighborhood relationships).

Thus, it can be stated that the value of a good is determined by its physical value as well as by the associated rights of action and property rights (Bodenstein-Koeppl, 2011, p. 46). As already explained in detail, the disposal transaction is often a legal transaction in rem, which is directed on a disposal over a thing and affects all persons directly. For the remainder of this paper, however, we will focus on the disposition transactions under the law of obligations, which are classified as relative disposition transactions. In the area of sports, especially in the application of football transfer transactions, these play an important role, as claims under the law of obligations can be asserted through the different contracts between the persons. In addition to intellectual property rights, property rights in professional football are the subject of this research paper.

\subsection{Football Transfers}

The first documented football transfer in history took place in 1893. The Scotsman Willie Groves transferred from West Bromwich Albion FC to Aston Villa for the sum of GBP 100 (Larkin \& Reeves, 2018). Nowadays, thousands of players change clubs every year and the transfer fees have increased many times over and can amount to several million euros. The previous record sum was reached in 2017 with a total of EUR 222 million and is unsurpassed so far. Player transfers are of great economic importance for clubs. Every year, thousands of professional football players change clubs. In so-called player transfers, a contracted athlete moves to another club (Stopper \& Karlin, 2018). In this process, the latter is usually released from a contract still in force with another club for payment of a certain transfer sum (Seip, 2017). In professional sports, these transfers have economic as well as sporting relevance for the respective club. When a player is sold, income can be generated, which can be invested in other players or also in the infrastructure of the club in each case. In addition, the money can be used for restructuring or improving financial stability if the club has debts or wants to improve its key figures. The latter is especially important for listed clubs, such as Borussia Dortmund or Manchester United, because potential investors, unlike fans, not only assess the sporting factors and their meaning for possible success of the club, but also review the economic parameters. Conversely, the purchase of a player can prove to be a worthwhile investment if the player performs as expected and the club can thus build on sporting successes and, in the best case, transfer the player on for a multiple of the invested sum.

In order for such transfers to take place, the federations, under the guise of FIFA (Federation Internationale de Football Association), have introduced rules to ensure that they are fair and regulated among the respective federations and their affiliated clubs. The organizations define a transfer as follows:

FIFA distinguishes between international and national transfers in its Regulations on the Status and Transfer of Players (FIFA, 2021, p. 7). 
- International transfer: the movement of the registration of a player from one association to another association.

- National transfer: the movement of the registration of a player at an association from one club to another within the same association.

The DFL (Deutsche Fußball Liga) defines a football transfer as follows: "Transfer" refers to the transfer of a player from one club to another (DFL, 2021).

The ten most expensive transfers ever made have now all broken through the EUR 100 million barrier. The most expensive transfer to date was made in the 2017/2018 season. At that time, the Brazilian player Neymar da Silva Santos Júnior moved from FC Barcelona to Paris Saint Germain for the sum of EUR 116 million.

\section{Process of a Transfer Based on an Example of the German Football Bundesliga}

Basically, it is first necessary to explain which parties carry out a transfer. Essentially, three players are involved in a football transfer:

1. The player who wants to change the club,

2. the club that releases the player, and

3. the club that takes the player.

Before the actual transfer takes place, a club first expresses interest in a player who is under contract to another club (DFL a). If the player agrees to the transfer, an agreement with the potential future club is reached regarding an employment contract. In the process, the transferring and receiving clubs agree on a transfer fee to be paid and conclude a so-called transfer contract (DFL b).

An example from the German Football League will be used to illustrate exactly how the transfer process works. In essence, the contents of the contract will not be discussed.

Player A has negotiated with club $\mathrm{C}$ and wants to transfer from club $\mathrm{B}$ to club $\mathrm{C}$ in Germany for the summer transfer period. After all parties have become involved and A, B, and $\mathrm{C}$ have agreed on a transfer, the transfer must be reported to the organization responsible for licensing players, here the DFL. This is done through the DFL Transfer-OnlineRegistration-System (TOR-System). It should be noted that the majority of the required documents must be submitted by 6 p.m. on the last day of the transfer period (DFL b). According to FIFA regulations, the national association may only define two transfer periods in which the player's transfer may be completed. In German professional football, these are the summer transfer period I and the winter transfer period II (DFL b). Until 2015, there was a so-called transfer list in Germany. The document was publicly available and listed all football players that a club wanted to transfer. However, if a player was not on this list, the transfer could not be carried out. This sometimes led to problems because of the countless number of physical documents and the sending of these to the DFL. It was not uncommon to read in the newspaper that a transfer could not be carried out because the fax machine of a football manager did not work shortly before the deadline (RevierSport, 2011). To remedy the problem and future disputes with clubs and player advisors, the German Football League introduced the Transfer Online Registration System (TOR system) for the 2015/2016 season. Using this platform, clubs in the 1st and 2nd Bundesliga can handle any licensed playerrelated processes. The scope of the documents to be submitted to the DFL depends on the scope of the transfer. A maximum of ten different documents, such as the employment contract and the sports fitness test, can be part of the transfer. If all regulations are met, the player is allowed to change clubs after passing a medical examination.

In 2019, FIFA registered a total of 18,047 football transfers and a year later, despite the COVID-19 pandemic in 2020, 17,077 football transfers of players from 180 different nations 
were made. However, only 14,432 players actually changed clubs, as some players changed several times during the year due to special contract constellations, such as loan contracts between clubs or returns from clubs (FIFA, 2021, p.7). Of the total 17,077 transfers carried out in 2020, a total of 187 of the 211 FIFA-affiliated member associations were involved, ranging from one transfer to thousands. The number of clubs involved even increased by $0.4 \%$ compared to the previous year, reaching a new high of 4,178 involved clubs.

\section{Methods}

From the Transfermarkt.de platform, the data of the soccer matches of all clubs that played in the Bundeliga in the last season 2020/2021 were collected since the soccer season 2014/2015 until 2020/2021. Primary focus in the dataset creation was on the individual matches, the minutes played by the players and their market values at the time of the match. A total of 31,099 matches were evaluated. Due to missing data sets, e.g., clubs that were in the Bundesliga in the 2020/2021 season but not in the seasons before, adjustments had to be made. Finally, 3,067 matches were evaluated. Only winners and losers were analyzed. The data records with drawn matches were removed from the sample.

The weighted club value on the field was determined according to the following formula:

$$
\text { weighted player value }=\sum_{p=1}^{n} \frac{t p_{p} \times M V_{p}}{90}
$$

$\begin{array}{ll}\mathrm{n}= & \text { Number of players of one team in the game } \\ t p_{p} & \text { Minutes played of a match in the game } \\ M V_{p} & \text { Market value of the player }\end{array}$

The individual matches were then analyzed and the difference in the weighted values of the teams playing was determined.

For the second analysis, the standings and market values of the teams in the 2014/2015 to $2020 / 2021$ seasons were recorded in a panel data set.

A two-sample T-test is then used to compare the weighted player value in game of winners and losers. At the same time, in a regression analysis, the table positions are used to explain the market value of the team.

\section{Results}

The analysis of the data considered 1148 games where the winning team was used as reference values. Thus, the weighted player value of the losing team was subtracted from the weighted player value of the winning team. In the period under consideration, 621 or $54.1 \%$ of the games were won by teams with a higher weighted player value. 


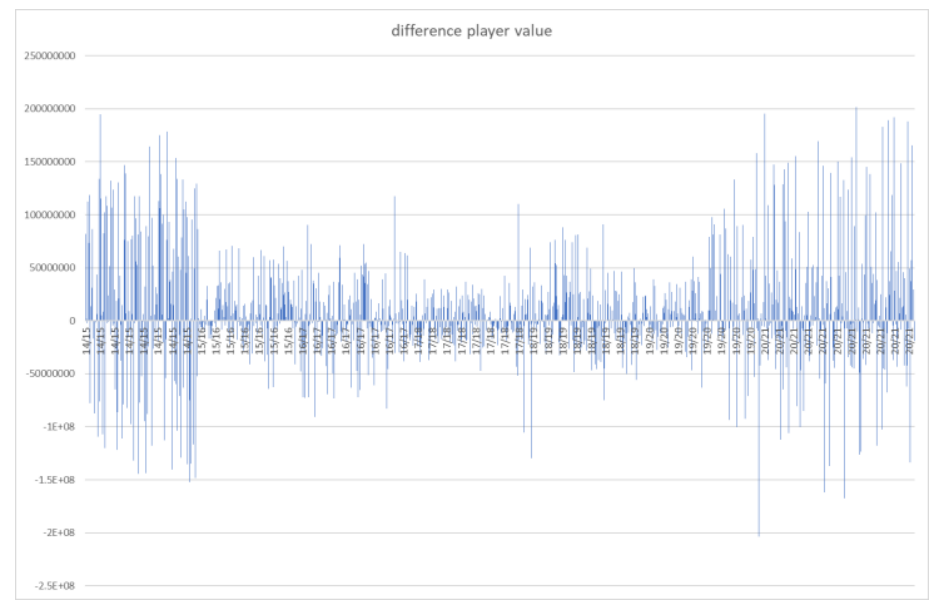

Figure 1. Differences in weighted player values between winners and losers.

Source: own presentation

The data set was further adjusted and a two-sample t-test revealed a significant difference between the weighted player value of the winning team and the weighted player value of the losing team in the amount of EUR 11.3 million.

Table 1. Two-sample t-test of weighted player scores between winning and losing teams.

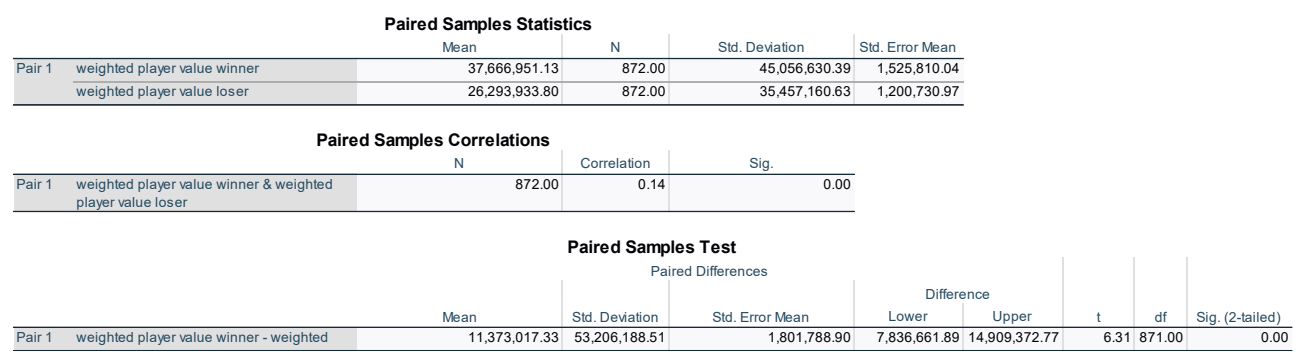

Source: own presentation

The regression analysis with the dependent variable difference player value, which was formed as the difference between the winning and losing teams, was explained by the dummy variables, won, lost and draw. Here we used a larger sample of 3065 records. 
Table 2. Regression of winner, loser and draw games on the difference player value

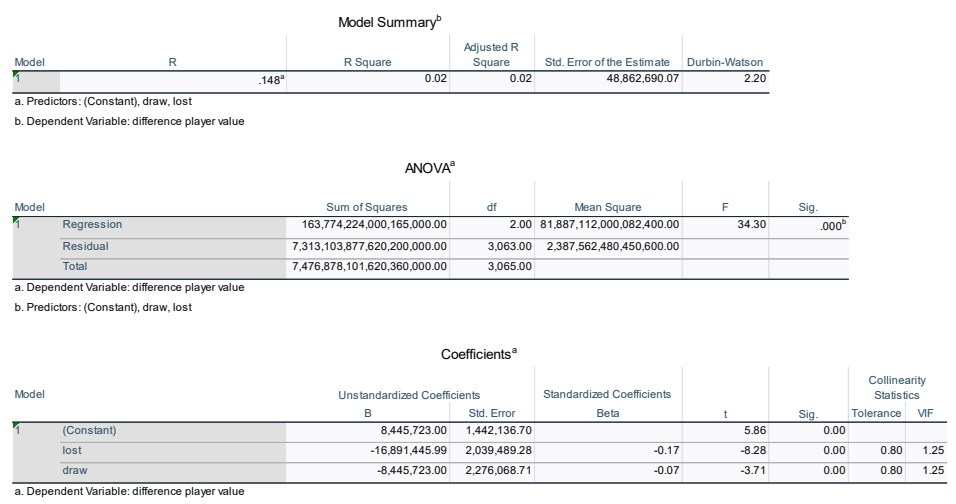

Source: own presentation

The results show that the difference player value can be significantly explained by the dummy variables. The winners were defined as the reference variable. The losers have a difference weighted player value that is EUR 16.9 million lower than the winners. The drawers have a value that is EUR 8.4 million lower.

In a binary regression, the win or loss of a match was predicted by the difference weighted player value. Only $57.6 \%$ of the winning games can be predicted correctly. This would bring us close to a random process.

Table 3. Binary winners and losers as dependent variable.

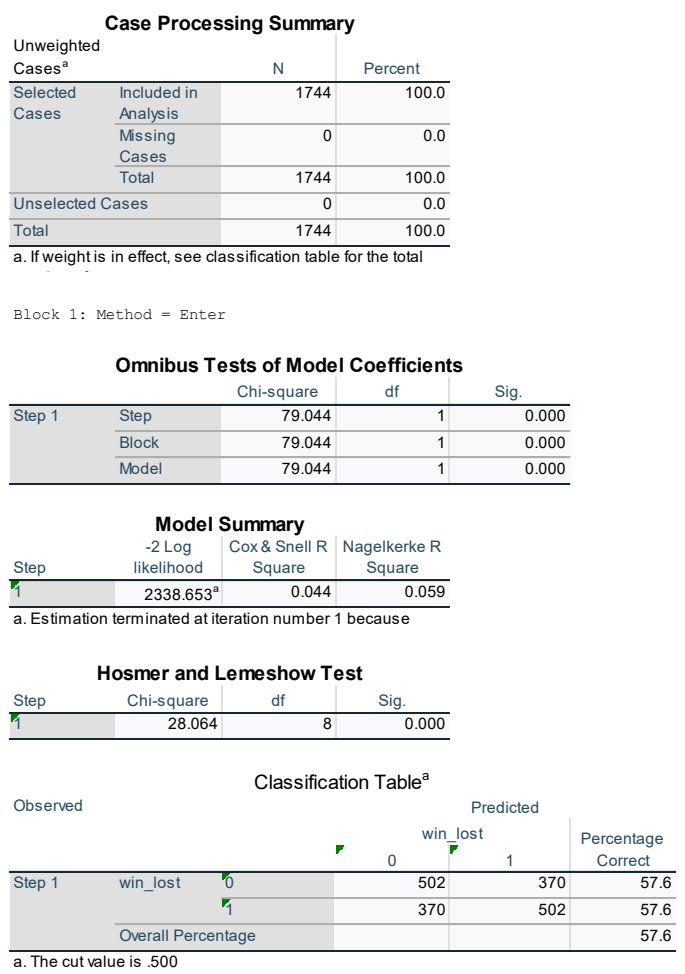


Source: own presentation

Finally, a panel data set was used to examine the Bundesliga table rankings with the associated market values. In the process, the rankings were adjusted for better understanding. Thus, 18th place in the analyses reflects first place in the table and vice versa.

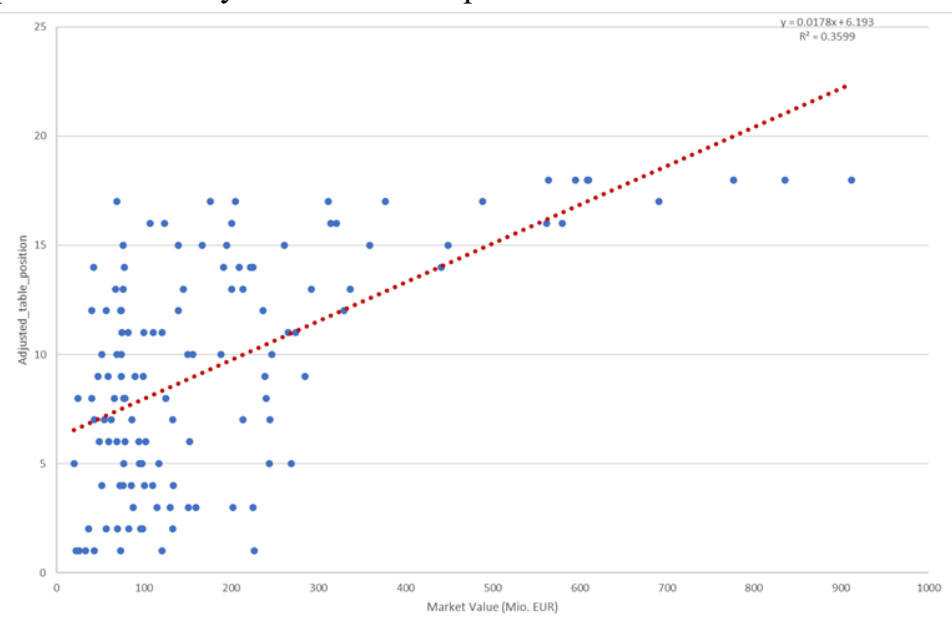

Figure 2. Relationship between table position and market values (2014/2015 to 2020/2021) of the Bundesliga.

Source: own presentation

A significant explanation of the table position by the market values is evident.

Table 4. Regression of table position (2014/2015 to 2020/2021)

\begin{tabular}{|c|c|c|c|c|}
\hline \multicolumn{5}{|c|}{ Model Summary } \\
\hline Model & $\mathrm{R}$ & R Square & $\begin{array}{l}\text { Adjusted R } \\
\text { Square }\end{array}$ & $\begin{array}{l}\text { Std. Error of the } \\
\text { Estimate }\end{array}$ \\
\hline 1 & $.600^{\mathrm{a}}$ & 0.360 & 0.355 & 4.184 \\
\hline
\end{tabular}

ANOVA $^{a}$

\begin{tabular}{l|l|r|r|r|r|r|r|}
\hline & & Sum of Squares & df & Mean Square & \multicolumn{1}{c}{ Sig. } \\
\hline 1 & Regression & 1220.700 & 1 & 1220.700 & 69.729 & $.000^{\mathrm{b}}$ \\
\hline Residual & 2170.800 & 124 & 17.506 & \\
\hline & Total & 3391.500 & 125 & & \\
\hline
\end{tabular}

a. Dependent Variable: Adjusted_table_position

b. Predictors: (Constant), Market Value (Mio. EUR)

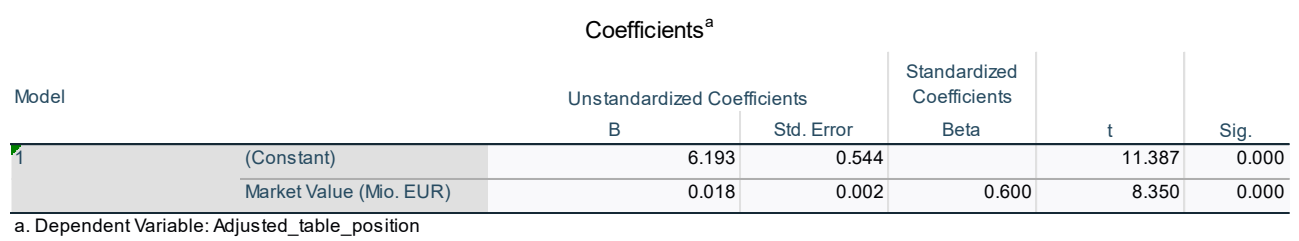

Source: own presentation 


\section{Discussion}

This paper investigated the influence of the market values of clubs and players on sporting success. It should be stated in advance that the explanatory power (r squared) was low in all models. It was found that in the Bundesliga, the market value of a team is a significant factor for the league position. The explanatory power of $35.5 \%$ is quite acceptable. Furthermore, based on the market value differences between winners and losers alone, no predictions can be made regarding the winning team. This is proven by the binary regression performed. It was also shown that the market values of winning teams are approximately EUR 16.9 million higher than those of losing teams. The difference between winners and draws was only EUR 8 million. In general, it should be noted that different results can be obtained by other models or differently set up correlations. This is recommended for further research contributions.

\section{References}

1. Bodenstein-Köppl, B. (2011). Transformation von Fernsehformaten in die Volksrepublik China. Gabler.

2. Bradley, P. S., Dellal, A., Mohr, M., Castellano, J., \& Wilkie, A. (2014). Gender differences in match performance characteristics of soccer players competing in the UEFA Champions League. Human Movement Science, 33, 159-171.

3. Demsetz, H. (1967). Toward a Theory of Property Rights. American Economic Review, 57(2), 347-359.

4. DFL. (n.d.). Klare Regeln: Das Spieler- und Transferwesen. Retrieved from: https://www.dfl.de/de/hintergrund/transferwesen/klare-regeln/

5. DFL. (n.d.). So läuft ein Transfer in der Bundesliga und 2. Bundesliga ab. Retrieved from: https://www.dfl.de/de/hintergrund/transferwesen/viele-schritte-bis-zur-spielbrech tigung-der-ablauf-eines-transfers/

6. Dimic, N., Neudl, M., Orlov, V., \& Äijö, J. (2018). Investor sentiment, soccer games and stock returns. Research in International Business and Finance, 43, 90-98.

7. Elaad, G. (2019). Do collective incentives enhance performance? A case study of reserve soccer teams. Journal of Behavioral and Experimental Economics, 80, 121-129.

8. FIFA. (2020). Global Transfer Market Report 2020: A review of International Football Transfers Worldwide. https://digitalhub.fifa.com/m/c54634f8bb5a641d/original/ijiz9 rtpkfnbhxwbqr70-pdf.pdf

9. Hackinger, J. (2019). Ignoring millions of euros: Transfer fees and sunk costs in professional football. Journal of Economic Psychology, 75, 102114.

10. Hoey, S., Peeters, T., \& Principe, F. (2021). The transfer system in European football: A pro-competitive no-poaching agreement?. International journal of industrial organization, 75, 102695.

11. Larkin, P., \& Reeves, M. J. (2018). Junior-elite football: time to re-position talent identification?. Soccer \& Society, 19(8), 1183-1192.

12. Morin, J. B., Le Mat, Y., Osgnach, C., Barnabò, A., Pilati, A., Samozino, P., \& di Prampero, P. E. (2021). Individual acceleration-speed profile in-situ: A proof of concept in professional football players. Journal of Biomechanics, 123, 110524.

13. Muller, O., Simons, A., \& Weinmann, M. (2017). Beyond crowd judgments: Data-driven estimation of market value in association football. European Journal of Operational Research, 263(2), 611-624. 
14. RevierSport (2011, January 31). Defektes Faxgerät verhindert Transfer! RevierSport. https://www.reviersport.de/fussball/1bundesliga/a145922---1-fc-koeln-defektes-faxger aet-verhindert-transfer.html

15. Seip, M. (2017a). C. Der Transfervertrag. In M. Seip (Ed.), Vertragsrechtliche und ökonomische Analyse des Spielertransfervertrages im Profifußball (pp. 39-115). Nomos Verlagsgesellschaft $\mathrm{mbH} \&$ Co. KG.Söllner, F. (2015). Die Geschichte des ökonomischen Denkens (4., korr. Aufl.). Springer-Lehrbuch. Springer Gabler.

16. Schäfer, H.-B., \& Ott, C. (2020). Lehrbuch der ökonomischen Analyse des Zivilrechts. Springer Berlin Heidelberg.

17. Schmid, H. (2013). Barrieren im Wissenstransfer. Springer Fachmedien Wiesbaden.

18. Stopper, M., \& Lentze, G. (Eds.). (2018). Handbuch Fußball-Recht: Rechte Vermarktung - Organisation (2., völlig neu bearbeitete und wesentlich erweiterte Auflage). Erich Schmidt Verlag.

19. The Guardian (2020). Men's transfer window summer 2020 - all deals from Europe's top five leagues. The Guardian. Retrieved from: https://www.theguardian.com/football /ng-interactive/2020/jul/30/transfer-window-summer-2020-all-deals-europe-premierleague-la-liga-bundesliga-ligue-1-serie-a

20. Truong, Q.-T., Tran, Q.-N., Bakry, W., Nguyen, D. N., \& Al-Mohamad, S. (2021). Football sentiment and stock market returns: Evidence from a frontier market. Journal of Behavioral and Experimental Finance, 30, 100472. 